\title{
Analysis of Consumer Behavior on Purchasing Meat Pork at Traditional Markets in Pematang Siantar City
}

\author{
A. M. Tanjung, H. A. Daulay*, and N. D. Hanafi \\ Animal Production Program Study, Faculty of Agriculture, Universitas Sumatra Utara, Padang \\ Bulan, Medan 20155 \\ *corresponding author :daulayarmyn@gmail.com
}

\begin{abstract}
Pork consumers prefer it because it has a unique taste. This study aims to determine the factors that influence meat pork consumer behavior and determine the potential segmentation of consumers in traditional markets. The study was conducted in the traditional markets of Pematangsiantar City, namely Horas and Dwikora Parluasan traditional market. It lasted from September 2020 until November 2020. In this study, primary data was obtained from observations and interviews with 70 consumers of meat pork buyers in traditional markets. Secondary data were obtained from related agencies such as the Central Bureau of Statistics and Animal Husbandary Department. The results showed that the characteristics of consumers influenced the potential segment of consumers in meat pork purchasing decisions. The variables of quality and number of families show a relationship of partial influence with the amount of consumption in the analysis of consumer behavior. However, the variables of age, occupation, education, income, and price of pork do not show a partial relationship with consumption.
\end{abstract}

Keywords: amount consumption, consumer behavior, pork, potential segments, traditional markets

Received [25 Juni 2021] | Revised [09 Juli 2021] | Accepted [23 Juli 2021]

\section{Introduction}

Meat is one of the essential livestock products in meeting human nutritional needs. The source of animal protein find in meat is relatively high, and there is a reasonably balanced content of essential amino acids. This high nutritive value makes meat the most popular consumption of livestock products by the Indonesian people and is added to the increasing public awareness of consuming animal protein. Indonesian people have many choices in consuming meat, including beef, chicken, duck, pork, and other meats. The demand for pork in Indonesia is relatively high after chicken, beef, and goat meat. Consumers of meat pork like meat pork because the meat of pork has a flavor unique. At 100 grams, pork is some composition of materials, including $41.1 \%$ water, $11.2 \%$ protein, $47 \%$ fat, $0.6 \%$ minerals, and $472 \mathrm{~kJ}$ calories[1].

Consumers have different characteristics that make every decision to buy pork vary. Various primary consumer considerations are the reasons for consumers to purchase pork. Consumer characteristics are part of consumer behavior, and producers who sell products need to know 
consumer characteristics, model decisions made by consumers, and innovate on pork attributes to attract consumer interest.

Consumer behavior is an actual action of individuals or groups of individuals, for example, an organization influenced by external and internal aspects that direct them to choose and consume the desired goods or services[2]. Understanding consumers and the consumption process will yield benefits, namely the ability to help managers make decisions[3].

Someone has a mindset in determining the decision to buy an item because the item is helpful for him. Likewise, a person uses a service because the service is beneficial for him. Before purchasing an item for consumption, consumers first look for information or are advised by someone to buy a specific item or service. This is a consumer behavior for consideration before choosing and consuming the goods or services needed[4].

Consumer behavior refers to the purchasing behavior of final consumers, namely individuals and households who buy goods and services for personal consumption. All these final consumers combine to form a consumer market. Consumer purchases are influenced by external factors, namely cultural and social, and internal factors, namely personal and psychological [5].

Consumption of livestock products is closely related to the ability or purchasing power of the community. There is a close and positive relationship between income levels and consumption behavior[6].

Based on this background, the researcher wants to know more about the factors influencing consumer behavior in consuming pork, segment potential consumers, and make pork purchasing decisions.

\section{Materials and Methods}

\subsection{Method of Research and Decision- Sample}

The research method used in this research is descriptive. Method of taking samples that are used is Convenience Sampling [7]. This is accepted as members of the sample are willing at the right time, quickly found, and accessible. How taking a sample is to obtain information from members of the population who can provide information that is needed. Respondents drawn from this study amounted to 70 people as consumers buying pork in the traditional markets of Horas and Dwikora Parluasan. Traditional markets are places where sellers and buyers meet and are marked by direct buyer-seller transactions, and usually, there is a bargaining process. The building usually consists of stalls or outlets, booths, and open grounds opened by the seller or a market manager[8]. 
Retrieval of samples to determine the behavior of the consumer by using the formula : $n=5 \mathrm{~K}$

Note : $\mathrm{n}=$ number of samples

$$
\mathrm{K}=\text { variable }
$$

Based on this formulation, it can be determined that the variables to be studied are seven variables, namely the quality variable, the age variable, the job variable, the income level variable, the education level variable, the meat price variable, and the number of a family variable so that the number of samples to be used in the study is 35 samples for each market.

\subsection{Types and Sources of Data}

In this research, the data used are primary data and secondary data. Primary data were collected from respondents, and data secondary is data obtained from various source agencies related that relate to research this as Agency Center for Statistics, the journal of research, and articles are required and linked to this research.

\subsection{Sample Collection Techniques}

The collection of data is done in research. This is the interview directly to the consumer buyer of pork in the traditional market town Pematangsiantar by way of filling the questionnaire and a list of questions that had been prepared.

\subsection{Data Analysis Methods}

To test the hypothesis first and reach the goal first of factors - factors that affect the purchase of pork in Pematangsiantar used Analysis Linear Regression (Multiple Regression Analysis) by SPSS (Statistical Product and Service Solution) where a variable bound (Y) is connected with two or the independent variable $(\mathrm{X})$.

\subsubsection{Test of Goodness of Fit}

\section{a. Coefficient of Determination (R2)}

The coefficient of determination R2 is a statistical value calculated from the sample data. This coefficient shows the percentage of variation in all dependent variables that can be explained by changes in the independent variables (explanatory variables).

\section{b. Simultaneous Test (F-Statistical Test)}

The $\mathrm{F}$ test is used to show whether all the independent variables included in the model simultaneously have a significant effect on the dependent variable. The $\mathrm{F}$ test is intended to determine the level of statistical significance of the regression coefficients simultaneously. 
c. Partial Test (T- Statistical Test)

The $\mathrm{T}$ test is used to show whether all the independent variables included in the model partially have a significant effect on the dependent variable. The test is entered to determine the level of statistical significance of the partial regression coefficients.

\subsubsection{Classic Assumption Test}

The classical assumption test is a statistical requirement that must be met in multiple regression analysis based on Ordinary Least Square (OLS). Three classic assumption tests will be used in this study, namely the normality test, heteroscedasticity, and multicollinearity.

\section{Result and Discussion}

\subsection{Potentian Consumer Segments}

Potential Segments Consumers of pork in traditional markets are a typical consumer characteristic in consuming an item. The determination of knowing the likely consumer segments and making it easier for pork sellers to target pork sales in traditional markets.

\subsubsection{Type of Work}

Types of work of the respondents, some of which are Civil Servants (PNS), self-employed / selfemployed, private employees, housewives and farmers. If it is described as follows:

Table 1. Frequency distribution of respondents based on type of work

\begin{tabular}{lrr}
\hline \multicolumn{1}{c}{ Profession } & Amount & Percentage \\
\hline Goverment employees & 4 & $5,71 \%$ \\
Entrepreneur/entrepreneur & 31 & $44,28 \%$ \\
Private employees & 8 & $11,42 \%$ \\
Housewife & 23 & $32,85 \%$ \\
Farmer & 4 & $5,71 \%$ \\
\hline Total & 70 & $100 \%$ \\
\hline
\end{tabular}

After counting the number of respondents, the most dominant is self-employed / self-employed, amounting to $44.28 \%$. Entrepreneurs / entrepreneurs are consumers who have irregular income. While the second dominant type of work is housewives, namely $32.85 \%$. Housewives are consumers who do not have permanent jobs and only take care of the household everyday. Meanwhile, the lowest types of work for consumers were civil servants and farmers, respectively $5.71 \%$.

\subsubsection{Level of Education}

There are several levels of consumer education found by researchers, namely SMP, SMA / SMK, Diploma and Higher Education. Consumers with high school / vocational education level 
dominate pork consumers as many as 42 respondents or $60 \%$ of the total research respondents. The number of respondents who graduated from SMA / SMK is related to the level of occupation of consumers as entrepreneurs / entrepreneurs and housewives. If it is described in Table 2 as follows:

Table 2. Frequency distribution of respondents based on education level

\begin{tabular}{lcc}
\hline \multicolumn{1}{c}{ Profession } & Amount & Percentage \\
\hline SMP & 1 & $1,42 \%$ \\
D3 & 5 & $7,14 \%$ \\
SMA/SMK & 42 & $60 \%$ \\
S1 & 21 & $30 \%$ \\
S2 & 1 & $1,42 \%$ \\
\hline Total & 70 & $100 \%$ \\
\hline
\end{tabular}

\subsubsection{Age}

In this study, age groupings were used which included children (5-14 years), young (15-29 years), adults (30-49 years) and old (> 50 years). The largest consumer age group is the adult age group, namely $72.85 \%$. This is because almost all adult age groups are housewives who meet the obligations of daily household needs. If it is described in Table 3 as follows:

Table 3. Frequency distribution of respondents by age

\begin{tabular}{lcc}
\hline \multicolumn{1}{c}{ Age (years) } & Amount & Percentage \\
\hline Children (5-14 years) & 0 & $0 \%$ \\
Young(15-29 years) & 4 & $5,71 \%$ \\
Adult (30-49 years) & 51 & $72,85 \%$ \\
Old (>50 years) & 15 & $21,42 \%$ \\
\hline Total & 70 & $100 \%$ \\
\hline
\end{tabular}

\subsubsection{Income}

The income level of consumers who buy pork the most are consumers with an income level of IDR. 2,000,000 - IDR. 3,000,000. Middle income consumers buy pork the most, this is due to the competitive price of pork offered in traditional markets so that the price is affordable for all groups. Respondents based on the income level in Table 4 are described as follows: 
Table 4. Frequency distribution of respondents based on income levels

\begin{tabular}{lcc}
\hline Income & Amount & Percentage \\
\hline <IDR 1.000.000 & 1 & $1,42 \%$ \\
IDR 1.000.000 - IDR 2.000.000 & 10 & $14,28 \%$ \\
IDR. 2.000.000 - IDR & 33 & $47,14 \%$ \\
3.000.000 & 22 & $31,42 \%$ \\
IDR. 3.000.000 - IDR & 2 & $2,85 \%$ \\
4.000.000 & 2 & $2,85 \%$ \\
IDR. 4.000.000 - IDR & 2 & $100 \%$ \\
5.000.000 & 70 & \\
>IDR 5.000.000 & & \\
\hline Total &
\end{tabular}

\subsection{Classic Assumption Test}

This test is done to test whether the data is suitable for use or not. The test was carried out by using the normality test, multicollinearity and heterocedesity. The following is an explanation of each of these tests.

\subsubsection{Normality Test}

Table 5. Normality Test

\begin{tabular}{lrr}
\hline Unstandardized Residual & & 70 \\
\hline $\mathrm{N}$ & & \\
& & \\
Normal Parameters & & 0 \\
& & \\
& Std. Deviation & 1,23873437 \\
& Absolute & 0,69 \\
Most Extreme Differences & Positive & 0,60 \\
& Negative & $-0,69$ \\
Test Statistic & & 0,69 \\
Asymp. Sig. (2-tailed) & & 0,200 \\
& &
\end{tabular}

Normality test aims to test whether in the regression model the confounding or residual variables have a normal distribution[9]. To find out, the Kolmogrov-Smirnov test was carried out. The Pvalue $=0.200$, which is greater than 0.05 , so it can be concluded that the residuals are normally distributed.

\subsubsection{Heterokedastic Symptom Test}

The attachment points spread above and below the number 0 on the Dependent Variable axis, so it can be concluded that there is no heteroscedasticity in the regression model. 


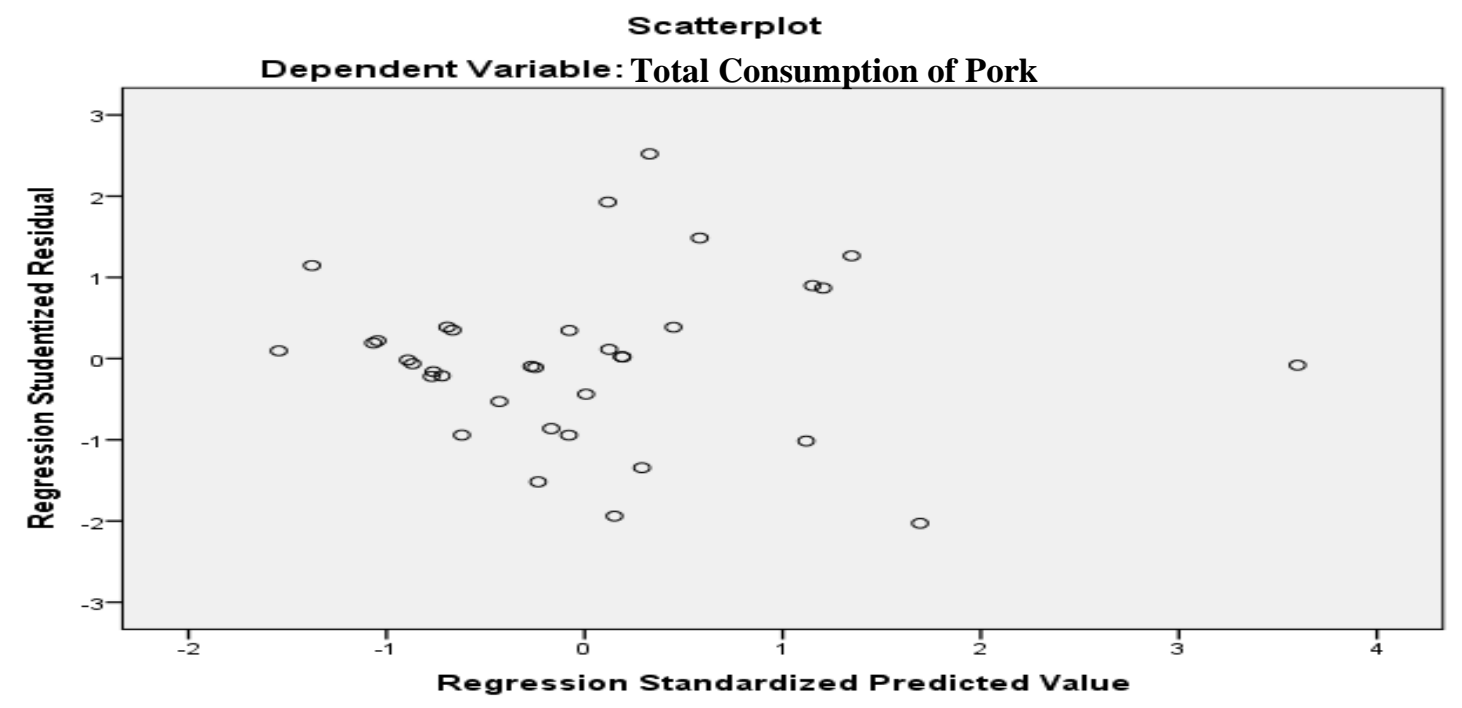

Figure 1. Heterokedastic Test

\subsubsection{Multicollinearity Test}

Multicollinearity test was conducted to test whether the regression model found a correlation between independent variables. Based on Table 6, the VIF value on the independent variable does not have more than 10 and tolerance is more than 0.1 , which means that there is no multicollinearity in the analyzed data and orthogonal variable.Orthogonal variables are independent variables whose correlation values are among variables[10].

Table 6. Multicollinearity Test

\begin{tabular}{lcc}
\hline Model & Tolerance & VIF \\
\hline Quality & 0,585 & 1,710 \\
Age & 0,776 & 1,289 \\
Profession & 0,815 & 1,226 \\
Income & 0,811 & 1,233 \\
Education & 0,579 & 1,727 \\
Pork Price & 0,811 & 1,233 \\
Families & 0,793 & 1,261 \\
\hline
\end{tabular}

Based on the classical assumption test, the data used have normal residual values, no heteroscedasticity, and no multicollinearity. So the data is suitable for further analysis.

\subsection{Regression Equations}

The regression estimation equation is a systematic formula that shows the relationship between one variable or several independent variables on other variables. The regression equation of the factors affecting the amount of pork consumption in Pematangsiantar City Traditional Market is as follows:

$\mathrm{Y}=3,581+(0,220) \mathrm{D} 1+(1,704) \mathrm{X} 2+(0,011) \mathrm{D} 3+(1,322) \mathrm{X} 4+(0,00000001546) \mathrm{X} 5+(-$ $0,022) \mathrm{X} 6+(-0,00003195) \mathrm{X} 7$ 


\subsection{Test of Goodness of Fit}

\subsubsection{Test The coefficient of determination $\left(R^{2}\right)$}

The coefficient of determination test is to determine how far the independent variable affects the dependent variable [11]. Based on the analysis, the coefficient of determination is 0.314 , which means that the independent variables that have been used are able to influence the dependent variable by $31.4 \%$ while $68.6 \%$ is influenced by other factors.

Table 7. Test The coefficient of determination $\left(\mathrm{R}^{2}\right)$

\begin{tabular}{ccccc}
\hline Model & $\mathrm{R}$ & $\mathrm{R}$ Square & Adjusted R Square & Std.Error of the Estimate \\
\hline 1 & 0,560 & 0,314 & 0,236 & 1,307 \\
\hline
\end{tabular}

\subsubsection{Simultaneous Test (F Statistics)}

Table 8. Simultaneous Test (F Statistics)

\begin{tabular}{lllcrc}
\hline Model & Sum of Squares & df & Mean Square & F & Sig \\
\hline Regression & 48,422 & 7 & 6,917 & 4,051 & 0,001 \\
Residual & 105,878 & 62 & 1,708 & & \\
\hline Total & 154,300 & 69 & & & \\
\hline
\end{tabular}

The statistical $\mathrm{F}$ test is a test to see the effect of the independent variables simultaneously affecting the fixed variable if the F-count> F-Table or the probability value is less than 0.05 . From the results of the analysis in Table 8 , it is found that the probability is smaller than 0.05 , which means that quality, age, occupation, income, education, price of pork, and several family members simultaneously affect the amount of pork consumption. Therefore, the next test is carried out, namely the statistical T-test, to see the variables that affect pork consumption.

\subsubsection{Partial Test (Statistical T Test)}

This partial test aims to determine what factors are among the independent variables that affect the amount of pork consumption in the traditional markets of Pematangsiantar city. If the independent variable has a probability smaller than 0.05 , the independent variable affects significantly the amount of pork consumption.

Table 9. Partial Test (Statistical T Test)

\begin{tabular}{lcc}
\hline Model & t-count & Sig \\
\hline (Constant) & 1,826 & 0,073 \\
Quality & 2,017 & 0,048 \\
Age & 1,601 & 0,115 \\
Profession & 0,489 & 0,627 \\
Income & 1,770 & 0,082 \\
Education & 0,067 & 0,947 \\
Pork Price & $-0,252$ & 0,802 \\
Families & $-2,885$ & 0,005 \\
\hline
\end{tabular}

From the results of the analysis in Table 9, it is found that the probability is smaller than 0.05 , which means that the quality and number of family members partially affect the amount of pork consumption. 


\subsection{Factors Affecting Pork Consumption}

\subsubsection{Quality (D1)}

The quality analysis on the total consumption of pork in the T-test is 0.048 , which is smaller than 0.05, which means that the quality level affects. Based on field observations, this is because consumers, before deciding to buy pork, have made observations about the pork to be purchased. Consumers will usually buy pork in large quantities in the morning because it is fresh straight from the slaughter. Consumers like pork that are still young because the meat is more tender. Older pork is generally redder than younger meat due to the high myoglobin content in more aged pork. Color pork quality is good in general red light [12].

\subsubsection{Age (X2)}

The analysis of age on the total consumption of pork in the T-test is 0.115 , more significant than 0.05, which means that age does not affect. It is not compatible with research under [13], which states pork consumption is not influenced significantly by age. The indication is that the respondent's age chooses a minor influence in decision-making on pork consumption. The results of the analysis of age on the total consumption of pork have a regression coefficient value of 1.704 , so every one-year increase in age causes an increase in beef consumption by 1.704 $\mathrm{kg} / \mathrm{month}$, assuming other variables are considered constant. The positive sign on age shows a positive effect on the amount of pork consumption, which means that if age increases, consumption will increase.

\subsubsection{Profession (D3)}

The result of the job analysis on the total consumption of pork in the T-test is 0.627 , which is greater than 0.05 , which means that the job does not affect it. This is because respondents who work related to the health sector consume large amounts of pork, even though pork can lead to high cholesterol. Still, they think consuming large quantities of pork can meet their nutritional intake and animal protein if appropriately processed. Likewise, with other respondents in Table 1 , most respondents do not work in the health sector, namely self-employed/self-employed and housewives. That way, the type of work does not affect the amount of pork consumption if, to meet the nutrition and animal protein, consumers must be competing to consume pork.

\subsubsection{Income (X4)}

The results of the income analysis on the total consumption of pork in the T-test is 0.082 , which is greater than 0.05 , which means that income does not affect it. This is not in line with research [14], which states that household income significantly affects pork consumption. Keintjem, in his study said that the higher a person's income, the purchasing power of an item would increase. This aims to improve the quality of life of consumers as the number of income increases. The results of the income analysis on the total consumption of pork have a regression coefficient of 
1.322, so every increase in income increases by Rp. 1,000,000, causing an increase in pork consumption to increase by $1.322 \mathrm{~kg} / \mathrm{month}$, assuming other variables are considered constant. The positive sign on income indicates a positive influence on the total consumption of pork.

\subsubsection{Education (X5)}

The educational analysis on the amount of pork in the T-test is 0.947 , which is greater than 0.05 , which means that education does not affect it. This is not in line with research [15], which states that the education variable influences the demand for pork in the city of Bajawa with a $99 \%$ confidence level, where when the level of education is higher, the need for pork for consumption will increase in line with the increasing understanding of protein nutrition. Animal. The education regression coefficient value is 0.00000001546 , which means that if the level of education increases by one year, it will increase the amount of pork consumption by 0.00000001546 $\mathrm{kg} / \mathrm{month}$, assuming that other variables are considered constant. The positive sign on education shows a positive influence on the total consumption of pork, which means that if the level of education increases, the amount of consumption will increase. Pork Price (X6)

The results of the analysis of the price of pork on the amount of consumption in the T-test is 0.802 , which is greater than 0.05 , which means that the cost of pork does not affect it. This is in line with research [15] which states that the price of pork does not significantly affect the demand for pork. This proves that the public is still insensitive to raise prices for goods in the market. Based on the field, respondents tend to buy meat, not because of need but desire, so that the cost of pork is not a factor for the number or number of consumers purchase pork. Supposedly, if to meet protein needs, consumers can replace other options besides pork if the price of pork is rising to meet their needs. The regression coefficient value of Pork Prices is -0.022 , which means that if the price of pork increases by $1 \%$, it will reduce the amount of pork consumption by 0.022 $\mathrm{kg} / \mathrm{month}$, assuming other variables are considered constant. The negative sign on the price of pork shows a negative effect on the total consumption of pork, which means that if the cost of pork increases, the amount of consumption will decrease.

\subsubsection{Families (X7)}

The analysis of pork on the amount of consumption in the T-test was 0.005 less than 0.05 , which means that the number of family members affected. This is in line with research [13] which states that the number of family members significantly affects the amount of pork consumption by the coastal community of Lake Tondano. This phenomenon shows that increasing family members has an impact on purchasing decisions for pork. Demographic patterns affect the supply and consumption of livestock food products [16]. Based on the regression analysis results, the coefficient value of the number of family members is -0.00003195 , which means that every increase in the number of family members is one person. The amount of consumption will decrease $0.00003195 \mathrm{~kg} /$ month, assuming other variables are considered constant. The negative 
sign on the number of family members shows a negative effect on the amount of pork consumption, which means that if the number of family members increases, consumption will decrease.

\section{Conclusion}

The potential segments of consumers, which are the socio-economic characteristics of consumers, namely the type of work, income level, age, and education level, affect the amount of pork consumption. The factors that influence consumer behavior in the amount of pork consumption are external factors, namely the variable approach of quality and number of families, and internal factors, namely the inconsistent approach of age, occupation, education, income, and price of pork, have a simultaneous or overall effect on the total consumption of pork. Only external factors, namely the variable quality approach and the number of family members, partially influence the total consumption of pork. In contrast, internal factors, namely the inconsistent approach of age, occupation, education, income, and price of pork, do not partially affect the total consumption of pork. Consumers carry out the stages of purchasing decisions for pork, namely introduction of pork, search for pork information, evaluation of alternatives, buying decisions, and post-purchase evaluation. This is because consumers have a significant enough contribution in purchasing pork, but there are family factors (husband, wife, or children) as a moderating variable in influencing purchasing decisions.

\section{REFERENCES}

[1] Rahma, N.I. 2016. Klasifikasi Pola Rasa Daging Sapi dan Daging Babi Berbasis Electronic Tongue (Skripsi). Malang: Fakultas Sains dan Teknologi, Universitas Islam Negeri Maula Malik Ibrahim Malang.

[2] Umar, H. 2003. Riset Pemasaran dan Perilaku Konsumen. Gramedia Pustaka Utama, Jakarta

[3] Sunarto. 2006. Perilaku Konsumen. Penerbit Amus, Yogyakarta

[4] Lutfiah, S. 2006, Analisis Perilaku konsumen Pada Pembelian Daging Ayam di Kabupaten Jember . (Skripsi). Jember. Fakultas Pertanian Universitas Jember.

[5] Kotler, Philip. 2006. Manajemen Pemasaran, Jilid I, Edisi kesebelasn Jakarta, P.T Indeks Gramedia.

[6] Giang, Randi R. Pengaruh Pendapatan tehadap konsumsi buruh bangunan di kecamatan Pineleng, Jurnal emba VOL.1 No.3

[7] Wibisono, D. 2003. Riset Bisnis Panduan bagi Praktisi dan Akademis. Gramedia Pustaka Utama, Jakarta.

[8] Anggreini, A. 2010. Pasar Traditional dan Pasar Modern. 
[9] Online)http://njiee.blogspot.com/2010/04/pasar-tradisional-pasar-tradisional.html. Diakses tanggal 3Maret 2020

[10] Sujarweni VW. 2015 SPSS Untuk Penelitian Yogyakarta (ID): Pustaka Baru Press

[11] Sukirno, S. 2003. Penganta Teori Mikroekonomi (Edisi Ketiga). Jakartaa: Grafindo

[12] Ghozali Imam. 2005. Aplikasi Analisis Multivariate dengan Program SPSS. Edisi Ketiga. Semarang. Universitas Diponegoro.

[13] Supriana T. 2013. Pengantar ekonometrika. USU PRESS: Medan.

[14] Soeparno. 2005. Ilmu dan Teknologi Daging. Cetakan ke-4. Gadjah Mada University Press, Yogyakarta

[15] Kumaat, Brigita K., M. Elly., F.H.Wantasen. E., Kalangi., L.S. 2019. Analisis konsumsi daging babi oleh masyarakat pesisir danau tondano. Jurnal Zootec Vol. 39 No.2 : 249-256.

[16] Keintjem, R., F.S.G. Oley., G.D. Lenzun dan J. Pandey. 2016. Pengaruh pendapatan terhadap konsumsi daging babi di kecamatan Wanea kelurahan Ranotana Weru. Jurnal Zootec36(1): 139-146.

[17] Kumanireng, S.P.P., Lole, U.R., Niron, S.S. 2017. Analisis faktor-faktor yang mempengaruhi permintaan daging babi di kota Bajawa. Jurnal Nukleus Peternakan, Vol. 4 No. 1: 56-64.

[18] Elly, F.H., M. Manese., N.M. Santa and I.D.R. Lumenta. 2015. Analysis of livestock product consumption coastal household in North Minahasa Regency. Procedia Food Science 3(1) : $1-5$. 